\title{
PENGALAMAN PEREMPUAN DENGAN PERSALINAN PERVAGINAM DI USIA DINI DI DESA MAMBU TAPUA DAN BA'BA TAPUA DI WILAYAH KERJA PUSKESMAS MATANGNGA
}

\author{
Masniati $^{1}$ Musniati $^{2}$ Immawanti $^{3}$ \\ ${ }^{1}$ Fakultas Ilmu Kesehatan, Universitas Sulawesi Barat, Indonesia \\ 2 Program Studi S1 Keperawatan, Fakultas Ilmu Kesehatan, Universitas Sulawesi Barat, \\ Indonesia \\ ${ }^{3}$ Stikes Marendeng Majene, Indonesia \\ E-mail: masniati@unsulbar.ac.id
}

\section{EXPERIENCE OF WOMEN WITH LABOR IN VAGINAMES IN EARLY AGE IN TAMUA MAMBU VILLAGE AND TAPUA BA'BA IN WORKING AREAS MATANGNGA HEALTH CENTER}

\begin{abstract}
This study is to gain an understanding and explore in depth about the experiences of women with vaginal birth at an early age. The research design used is qualitative research with a phenomenological approach. The number of participants as many as five participants with different characteristics. Data collection through in-depth interviews that were analyzed using the Miles and Huberman model. Results: The experience of women with vaginal birth at an early age in the working area of the Matangnga puskesmas, showed a change in various aspects, namely the experience of women before delivery, perceptions of changes in postnatal lifestyle, the impact of early marriage, the role of health workers in health services, expectations for health services. Suggestions include: paying more attention to early-age couples who are pregnant or those who have given birth, giving counseling to women who are pregnant and giving birth at an early age, making local government or village regulations related to early marriage, further research, and input to maternity nursing programs.
\end{abstract}

Keyword: Childbirth, Vaginal, Early Age.

\begin{abstract}
Abstrak
Penelitian ini untuk mendapatkan pemahaman dan mengeksplorasi secara mendalam tentang pengalaman perempuan dengan persalinan pervaginam diusia dini. Desain penelitian yang digunakan adalah penelitian kualitatif dengan pendekatan fenomenologi. Jumlah partisipan sebanyak lima partisipan dengan karakteristik yang berbeda. Pengumpulan data melalui indepth interview yang dianalisa dengan menggunakan model Miles and Huberman. Hasil : Pengalaman perempuan dengan persalinan pervaginam diusia dini di wilayah kerja puskesmas Matangnga, menunjukkan adanya perubahan dalam berbagai aspek yaitu pengalaman perempuan menjelang persalinan, persepsi adanya perubahan pola hidup pasca melahirkan, dampak pernikahan di usia dini, peran tenaga kesehatan terhadap pelayanan kesehatan, harapan terhadap pelayanan kesehatan. Saran berupa : lebih memperhatikan pasangan usia dini yang sedang hamil maupun yang telah melahirkan, memberikan konseling pada perempuan yang hamil dan melahirkan di usia dini, membuat peraturan pemerintah atau desa setempat terkait pernikahan di usia dini, penelitian lebih lanjut, dan masukan untuk program keperawatan maternitas.
\end{abstract}

Kata Kunci: Persalinan, Pervaginam, Usia dini. 


\section{PENDAHULUAN}

Badan Kependudukan dan Keluarga Berencana Nasional (BKKBN) menyebutkan usia ideal menikah adalah 21 tahun untuk perempuan dan 25 tahun untuk laki-laki. Usia tersebut dianggap masa yang paling baik untuk berumah tangga, karena sudah matang secara biologis dan psikologis.

Berdasarkan data dari UNICEF (United Nations Children's Fund), Indonesia tercatat sebagai salah satu dari 10 negara di dunia atau tepatnya di urutan ketujuh di dunia dan urutan kedua di ASEAN dengan angka perkawinan anak tertinggi. UNICEF mengestimasi setiap tahun 12 juta perempuan memutuskan menikah dini di seluruh dunia. Merujuk kepada Badan Sasaran Pembangunan Berkelanjutan PBB, UNICEF menargetkan dunia bebas praktik pernikahan di bawah umur pada 2030 mendatang. Prevalensi perkawinan usia anak lebih banyak terjadi di pedesaan dengan angka 27,11 persen, dibandingkan di perkotaan berada pada angka 17,09 persen.
Di Sulawesi Barat, fenomena ini telah banyak terjadi, dan menjadi problem krusial di Sulawesi Barat. Hasil data Survei Demografi dan Kesehatan Indonesia (SDKI) tahun 2012 Sulawesi Barat menunjukkan rata-rata usia kawin pertama yaitu 19 tahun. Berdasarkan sumber data tersebut, rendahnya usia kawin pertama perempuan di Sulawesi Barat berakibat pada tingginya angka kelahiran usia dibawah 20 tahun. Ini ditunjukkan dengan data 103 kelahiran per 1000 wanita umur 15 sampai 19 tahun, atau 10 kelahiran per 100 wanita atau 1 kelahiran per 10 wanita umur 15 sampai 19 tahun. Badan Pusat Statistik Sulawesi Barat tahun 2015 juga merilis data bahwa ada $11,58 \%$ wanita di Provinsi Sulawesi Barat menikah di bawah usia 16 tahun. Dan juga prevalensi terbesar di Indonesia untuk anak perempuan yang menikah di bawah usia 15 tahun. Menurut data dari BPS (Badan Pusat Statistik) pada tahun 2016, rata-rata perkawinan anak di Sulawesi Barat sebesar 37\%. Hal ini diperkuat dengan pendataan keluarga terkait usia kawin pertama di Sulawesi Barat tahun 2017, bahwa perempuan yang menikah dibawah usia 21 tahun mencapai 114.741 orang dan laki-laki yang menikah 
dibawah usia 25 tahun mencapai 94.567 orang.

Berdasarkan data BPS tahun 2018, Jumlah ibu hamil di Provinsi Sulawesi Barat pada tahun 2017 yaitu sebanyak 32.362 orang. [3] Sebanyak 10 persen remaja usia 15-19 tahun sudah pernah melahirkan atau sedang hamil anak pertama (survey demografi dan kesehatan, 2012).

Remaja mudah menghadapi risiko komplikasi dan kematian yang lebih tinggi sebagai akibat kehamilan dibandingkan wanita lain. komplikasi selama kehamilan dan persalinan merupakan penyebab utama kematian dan kecacatan di antara wanita usia reproduksi di Negara berkembang. Komplikasi yang menyebabkan hampir $75 \%$ dari semua kematian ibu adalah perdarahan hebat, infeksi, tekanan darah tinggi selama kehamilan, aborsi yang tidak aman, dan penyakit selama kehamilan (WHO, 2018).

Salah satu target SDGs (Sustainable Development Goals) periode 2016-2030 adalah pada tahun 2030 mengurangi rasio kematian ibu melahirkan global menjadi kurang dari 70 per 100.000 kelahiran hidup. Berdasarkan data Riskesdas Kementrian Kesehatan Republik Indonesia, AKI (Angka Kematian Ibu) di tahun 2017 sebanyak 1.712 kasus. Jumlah kasus kematian ibu di Provinsi Sulawesi Barat tahun 2017 yaitu sebanyak 39 dan Kabupaten Polewali Mandar menjadi Kabupaten dengan angka terbesar jumlah kasus kematian ibu yaitu sebanyak 11 orang (Profil Kesehatan Provinsi Sulawesi Barat, 2017).

Kehamilan dan kelahiran akan membawa perubahan yang sangat besar bagi seorang wanita, disamping perubahan fisik, juga terdapat perubahan pada kondisi psikisnya, oleh karena itu dalam menghadapi kehamilan dan kelahiran dibutuhkan persiapan fisik dan psikis (Regina, dkk dalam Rusli,2011).

Proses persalinan normal merupakan proses lahirnya bayi dengan serangkaian kejadian yang dipersepsikan menakutkan dan menimbulkan rasa sakit yang luar biasa.

Usia ideal bagi seorang wanita untuk hamil dan melahirkan terutama kehamilan pertama adalah antara usia 20 sampai 30 tahun. Pada periode ini, resiko wanita menghadapi komplikasi medis ketika hamil dan melahirkan tergolong yang paling rendah (Sloanne \& Benedict,2009). Di kurun umur ini, angka kematian ibu melahirkan dan bayi meningkat, sehingga akan meningkatkan 
kecemasan (Astria, 2009). Jika seorang memutuskan untuk hamil diluar rentan usia tersebut maka akan rentang untuk mengalami kehamilan dan persalinan yang beresiko tinggi, baik itu secara fisik maupun psikis.

Sekalipun peristiwa kelahiran sebagai fenomenal fisiologis yang normal, akan tetapi kenyataannya proses persalinan berdampak terhadap kesehatan fisik seperti perdarahan,anemia, kesakitan yang luar biasa serta bisa menimbulkan ketakutan bahkan kematian baik ibu ataupun bayinya (Janiwarty \& Pieter, 2012). Resiko kehamilan yang tinggi akan terjadi apabila seorang wanita mengalami kehamilan dan melahirkan dibawah umur 20 tahun dan diatas 35 tahun (Depkes RI 2007).

Tidak hanya trauma fisik yang muncul sebagai akibat dari kehamilan dan persalinan pada masa remaja, proses persalinan juga seringkali mengakibatkan aspek-aspek psikologis sehingga menimbulkan berbagai permasalahan psikologis. Semakin dekatnya persalinan, wajar timbul perasaan cemas atau takut (Marmi, 2011).National Institute of Mental Health (2005) di Amerika Serikat terdapat 40 juta orang berusia kurang dari 20 tahun mengalami gangguan kecemasan (ansietas) menjelang persalinan. Pasca persalinan- pun menimbulkan permasalahan psikologis seperti post partum blues atau baby blues atau maternity blues, postpartum depresi, postpartum psikosis. Salah satu penyebabnya adalah pengalaman dalam persalinan yang kurang menyenangkan yang dapat mempengaruhi perubahan psikologis setelah melahirkan pada semua ibu post partum dari etnik dan ras manapun, dan dapat terjadi pada ibu primipara maupun multipara (Mansyur, 2014). Secara psikis, memang umumnya remaja belum siap untuk menjalankan perannya sebagai seorang ibu sehingga yang muncul adalah ketegangan mental dan kebingungan akan peran sosial yang berubah dari seorang gadis remaja kemudian hamil dan menjadi seorang ibu.

Suatu penelitian yang sama juga dilakukan oleh beberapa Negara seperti di Swedia, Australia, Italia dan Indonesia itu sendiri dengan menggunakan EPDS (Edinburg Postnatal Depression Scale) untuk mengetahui postpartum blues (Suherni, 2012). Angka kejadian postpartum blues di Asia cukup tinggi dan sangat bervariasi antara 26\% sampai $85 \%$ (Iskandar, 2014). Sedangkan di Indonesia angka kejadian postpartum blues antara $50 \%$ sampai $70 \%$ dari wanita pasca persalinan (Hidayat, 2014). 
Tujuan penelitian ini untuk mendapatkan pemahaman dan mengeksplorasi secara mendalam tentang pengalaman perempuan dengan persalinan pervaginam diusia dini di Desa Mambu Tapua dan Ba'ba Tapua di wilayah kerja Puskesmas Matangnga.

\section{BAHAN DAN METODE}

Jenis penelitian ini menggunakan metode deskriptif kualitatif dengan desain penelitian fenomenologi yang berfokus pada penemuan fakta terkait pengalaman hidup individu untuk mengeksplorasi secara mendalam terkait pemahaman dan pengalaman perempuan dengan persalinan pervagina di usia dini.

Penelitian kualitatif dengan pendekatan fenomenologi berusaha mengungkapkan makna untuk mengetahui dan memahami fenomena atau pengalaman yang terjadi dalam kehidupan partisipan yang didasari oleh kepercayaan dan nilainilai yang dimiliki sesuai sudut pandangnya masing-masing. Penelitian ini dilakukan dalam situasi yang alami, sehingga tidak ada suatu batasan dalam memaknai atau memahami fenomena yang dikaji (Creswell, 2015 ; Afiyanti \& Rachmawati, 2014).
Partisipan dalam penelitian ini adalah perempuan dengan persalinan pervagina di usia dini di Desa Mambu Tapua dan Ba'ba Tapua. Teknik pengambilan sampel pada penelitian kualitatif ini menggunakan tehnik Purposive Sampling dengan kriteria inklusi : (1) Ibu primipara maupun multipara yang pernah melahirkan pervagina diusia dini (di bawah usia 19 tahun). (2) Mampu mengungkapkan pengalaman dengan lancar. (3) Bersedia menjadi partisipan.

Instrument dalam penelitian ini yaitu Hand Phone untuk merekam informasi dari partisipan, pedoman wawancara untuk membantu peneliti mengajukan pertanyaan yang berorientasi pada tujuan penelitian, serta catatan lapangan yang dibuat pada saat wawancara berlangsung dalam melihat kondisi atau ekspresi dari partisipan. Teknik wawancara yang digunakan adalah wawancara mendalam (in-depth interviewing) selama 40 sampai 60 menit untuk setiap partisipan atau sesuai kesepakatan.

Teknik analisa data yang digunakan peneliti menggunakan model Miles and Huberman. Dalam penelitian kualitatif, analisa data dilakukan pada saat pengumpulan data berlangsung dan setelah selesai pengumpulan data selama periode 
tertentu (Miles and Huberman, 1984 dalam Sugiyono, 2007). Proses analisa data akan dilakukan dengan metode fenomenologi.

Empat prinsip utama dalam etik penelitian keperawatan yang diperhatikan dalam penelitian ini yaitu menghormati harkat dan martabat, menghormati privasi dan kerahasiaan subjek, menghormati keadilan dan inklusivitas, serta memperhitungkan manfaat dan kerugian yang ditimbulkan.
Teknik operasional yang dapat meningkatkan keakuratan dalam penelitian ini

adalah credibility, dependability, confirmability, dan transferability (Saryono \& Anggraeni, 2013 : Sugiyono, 2016).

HASIL

Partisipan dalam penelitian ini berjumlah lima orang. Semua partisipan bertempat tinggal di wilayah kerja Puskesmas Kecamatan Matangnga.

\begin{tabular}{cccccc}
\hline NO & P1 & P2 & P3 & P4 & P5 \\
\hline 1 & 20 & 20 & 19 & 18 & 18 \\
2 & 2 & 2 & 2 & 1 & 3 \\
3 & 17 & 14 & 14 & 18 & 13 \\
& Norm & Norm & Norm & Normal dengan rupture & Normal \\
4 & al & al & al & perineum dan perdarahan & Islam \\
5 & Islam & Islam & Islam & Islam & SD \\
6 & SMP & SD & SD & SMP & IRT \\
7 & IRT & IRT & IRT & IRT & \\
\hline
\end{tabular}

\section{Keterangan}
* 1 : kode partisipan
2: usia
3: status paritas
4: usia melahirkan pertama
$5:$ proses persalinan terakhir
6 : agama
7 : pendidikan terakhir
8 : pekerjaan 
Jurnal Kesehatan Masyarakat, Vol. xx, No. x, 20xx: xx - xxp-ISSN: 2442-8884 / e-ISSN: 2541-4542

http://dx.doi.org/10.35329/jkesmas.vxxixx

\section{Pembahasan}

penelitian ini menghasilkan lima tema yang menggambarkan suatu

fenomena pengalaman perempuan dengan persalinan pervaginam di usia dini. Tematema tersebut yaitu (1) pengalaman perempuan menjelang persalinan, (2) persepsi adanya perubahan pola hidup pasca melahirkan, (3) dampak pernikahan di usia dini, (4) peran tenaga kesehatan terhadap pelayanan kesehatan, (5) harapan terhadap pelayanan kesehatan.

TEMA 1 merupakan pengalaman perempuan menjelang persalinan yang dialami partisipan terbagi atas dua kategori yaitu faktor internal seperti Nyeri punggung, perut, Perasaan seperti mau BAB, Keluar lendir bercampur darah, Air ketuban pecah, Perasaan menggigil.

Mengedan, Sakit diarea kemaluan. Faktor eksternal yaitu Syahadat, Tarik nafas dalam, Mengelus-elus perut dan tangan, Percaya diri, Berjalan, Kepercayaan, Perbanyak istghfar, Jangan mengeluh, semangat, Berdo'a, mengingat Allah dan berfikir positif, Minum air putih yang sudah dibacakan do’a, Di mandikan, Dioleskan daun-daun. Pengalaman semua partisipan dalam penelitian ini yang paling banyak dialami adalah nyeri punggung, perasaan seperti mau $\mathrm{BAB}$, ketuban pecah, mengedan dan sakit diarea kemaluan, berjalan, syahadat, dan percaya diri seperti pada pernyataan berikut :

"pada saat saya mau melahirkan itu...rasanya kayak mau buang air besar.. mulai keluar darah dan juga belakang agak sakit sedikit sama paha (terlihat meringis sambil memegang punggung dan paha)...mungkin air ketuban ya pecah di jalan pas jalan ke rumah...2, 3 kali mengedan.. Sakitnya itu dibagian ini (menunjuk kemaluan) pas anaknya mau keluar.." (P1)

Hal ini sesuai dengan teori yang di kemukakan oleh Manuaba (2012) bahwa beberapa tanda di mulainya persalinan yaitu dengan cirri khas pinggang terasa nyeri menjalar ke depan (perut), pengeluaran lendir bercampur darah, pecahnya selaput ketuban, perubahan pada serviks (perlunakan, pendataran, dan pembukaan serviks), adanya dorongan mengedan, tekanan dari anus, menonjolnya perineum, pengeluaran plasenta.

"kalau saya toh selalu jalan begitu, jalan-jalan, kalau duduk $k i$ na sakit lagi begitu ya jalan $k i$ lagi. Berkurang lagi sakitnya kurasa kalau jalan ka lagi. Kalau rasa takut $\mathrm{ku}$, ya pokoknya syahadat terus... ya diserahkan saja sama Tuhan.” (P4)

Hal ini sejalan dengan pendapat Alkahel (2011), yang menyatakan bahwa Al- 
Qur'an yang di perdengarkan atau diucapkan akan memberikan efek relaksasi sebesar 65 \%. Terapi bacaan Al-Qur'an terbukti mengaktifkan sel-sel tubuh, menurunkan stimuli reseptor nyeri, memberikan efek distraksi dan relaksasi pada pasien nyeri.

TEMA 2 adalah persepsi adanya perubahan pola hidup pasca melahirkan seperti mengurus suami dan anak, mengurus pekerjaan rumah tangga, sabar, saling pengertian, saling membantu, dan menjadi yang terbaik. Seperti pernyataan berikut :

“...kita berusaha bagaimana mengurus suami dan juga anak. Pekerjaan sana-sini, mana lagi urus anak, mencuci apa segala...saya itu harus sabar. Kalau dia marah saya pergi tinggalin dia, kalau saya yang marah dia juga pergi. Makanya kita harus saling pengertian.” (P1)

"awal ka saya menikah masih sama ka orang tua $\mathrm{ku}$, nabantu ka orang tuaku mengurus semuanya seperti bergantian ka di dapur... kalau saya memasak ka, bersihkan rumah, ya ituji. Tapi ya sekarang ini merasa sibukmi apa' sendirimi belum lagi ada anak, suamita, memasak paki, ya sibuk... berusaha maki jadi yang terbaik...ya anu sabar ka apa, bagaimana adami juga anak ku...”(P3)

Hal ini dinyatakan melalui penelitian yang dilakukan oleh Emilia Puspitasari dan Candra Hadi (2018) bahwa ibu primigravida adalah seoang wanita yang baru pertama kali mengalami proses kelahiran anak pertama dalam keluarga dan merupakan situasi krisis bagi seorang wanita karena ada perubahan peran dan pola hidup seseorang yang di pengaruhi oleh pengalaman yang dimiliki oleh ibu dalam melakukan perawatan mandiri setelah melahirkan. Sama halnya yang di jelaskan dalam buku wawasan Al-Qur'an karya Shihab, M Quraish (1996) yang kemudian di ungkapkan oleh Halimatussa'diyah dalam penelitian kepustakaannya, bahwa islam bertujuan menciptakan kedamaian dan ketentraman dalam pernikahan, oleh karena itu suami istri harus saling membantu. Kemudian istri bersama suami bertanggung jawab menjaga keharmonisan rumah tangga dan menciptakan ketenangan untuk semua anggota keluarga. Menurut Parson, yang dijelaskan dalam penelitian Syamsuddin (2018) bahwa keluarga yang terbentuk, dimana anggota keluarga di dalamnya memiliki tugas masingmasing seperti ayah sebagai kepala keluarga yang memiliki tanggung jawab terhadap perlindungan dan menjaga kesehatan keluarga, sedangkan ibu bertanggung jawab dalam urusan rumah tangga dalam mensejahterahkan keluarganya.

TEMA 3 merupakan dampak pernikahan diusia dini. Semua partisipan menunjukkan dampak fisik yang dilihat dari komplikasi selama kehamilan dan persalinan serta dampak psikis yang dilihat dari 
Jurnal Kesehatan Masyarakat, Vol. xx, No. x, 20xx: xx - xxp-ISSN: 2442-8884 / e-ISSN: 2541-4542

http://dx.doi.org/10.35329/jkesmas.vxxixx

perubahan sikap pasca berumahtangga. Seperti halnya pernyataan pertisipan berikut :

“...kalau suami ya itukan apa’ biasa tidak sependapat $k i$, biasa $k i$ itu tidak baku cocok ya begitu mi apalagi sekarang di'mmmcceehhh ya begitu mi (terlihat semakin-berkaca-kaca). Susah ki mangnganu batin ta apa' nda baku cocok ki (mulai menangis). Kalau masalah menderita batin ya kurasakan $m i$ saya bagaimana itu dibilang suami ta (semakin menangis)... simata begitu $m i$ sedikit tidak ee ada tidak nasuka, marah...kuhargai juga tapi ya begitu $m i$ (menarik nafas panjang)...”(P3)

Hal ini sesuai dengan penelitian yang dilakukan Adham (dalam Purnawati, 2015) bahwa pasangan yang melangsungkan pernikahan pada usia remaja tidak bisa memenuhi atau tidak mengetahui apa yang menjadi hak dan kewajiban sebagai suami dan istri. Hal tersebut disebabkan karena remaja belum matang baik secara fisik ataupun mental serta masih memiliki keegoisan yang tinggi. Hal yang sama juga di ungkapkan oleh Mery, Dien dan Livia (2015) dalam penelitiannya bahwa dari segi psikologis, karena keterbatasan dan ketidakmatangan untuk berumah tangga, anak perempuan yang terpaksa menjadi seorang istri di usia yang masih sangat belia tidak memiliki posisi tawar-menawar dengan suami sehingga sangat rawan menjadi korban dan sasaran kekerasan dalam rumah tangga. “...sempat ka pendarahan, perasaan ku waktu itu ya pusing tidak melihat apa-apa, pokoknya pusing kalau melihat ki toh cuman gelap saja dilihat...saya merasa sakit itu ada lebih satu bulan saya dulu itu menderita, manapi dia tete' ku bengkak disusui sama anak $\mathrm{ku}$ itu, manapi lagi saya soal itu pendarahan sedikit masih ada keluar darah sedikit, pada pokoknya masih selalu berdarah, kadang juga pusing ka, biasa sakit kepala ku, lemas ka juga apa lagi makan ku ya $t a$ ' sedikit-sedikit, asal ada ku makan....”(P4)

Hal yang sama juga di ungkapkan oleh Mery, Dien dan Livia (2015) dalam penelitiannya bahwa kehamilan usia remaja membawa resiko anemia karena kekurangan zat besi, perdarahan, abortus, persalinan yang lama dan sulit, sampai dengan terjadinya kematian. Perempuan yang hamil di bawah usia 20 tahun 58,5\% lebih rentan menderita kanker serviks. Dan resiko yang akan terjadi pada bayi antara lain, bayi lahir premature, berat badan lahir rendah, cacat bawaan hingga kematian bayi. Kematian bayi 50\% lebih tinggi pada ibu usia remaja.

TEMA 4 adalah peran tenaga kesehatan terhadap pelayanan kesehatan. Peran yang paling banyak di jelaskan partisipan yaitu mengontrol ibu hamil dan melahirkan serta pendidikan kesehatan kepada ibu hamil dan melahirkan. Seperti pada salah satu pernyataan berikut : 
Jurnal Kesehatan Masyarakat, Vol. xx, No. x, 20xx: xx - xxp-ISSN: 2442-8884 / e-ISSN: 2541-4542

http://dx.doi.org/10.35329/jkesmas.vxxixx

"...datang saja itu menjengu, melihat, nakasih ki obat-obatan macam pattambah darah ya yang lain-lain supaya sehat ka kembali, segar ka kembali tidak merasa lemas ka tidak ada sakit-sakit di badan ku...biasa juga na kontrol darah ku, na tanya supaya makan-makan sayuran, buah-buahan supaya sehat-sehat juga anak ku, tidak boleh ki juga banyak pikiran harus $a n u$, sehat dirasa.”(P3)

Hal ini sesuai ungkapkan Mery, Dien dan Livia (2015) dalam peneltiannya bahwa petugas kesehatan selaku educator berperan dalam melaksanakan bimbingan atau penyuluhan, pendidikan pada klien, keluarga, masyarakat dan petugas kesehatan termasuk siswa bidan/keperawatan terkhususnya yang berhubungan dengan dengan kesehatan reproduksi termasuk mengenai kehamilan dan persalinan di usia remaja. Peran sebagai penyuluh yaitu dilaksanakan dengan proses pemberian bantuan yang dilakukan melalui wawancara petugas kesehatan kepada individu yang yang sedang mengalami masalah kesehatan. Sebagai motivator, petugas kesehatan berkewajiban untuk mendorong perilaku positif dalam kesehatan, dilaksanakan konsisten dan lebih berkembang. Untuk selaku fasilitator, tenaga kesehatan harus mampu menjembatangi dengan baik antara pemenuhan kebutuhan keamanan klien dan keluarga sehingga faktor resiko dalam tidak terpenuhinya kebutuhan keamanan dapat diatasi, kemudian membantu keluarga dalam menghadapi kendala untuk meningkatkan derajat kesehatan.

TEMA 5 adalah harapan terhadap pelayanan kesehatan. Harapan-harapan mereka yaitu dua partisipan menginginkan tenaga kesehatan harus aktif di puskesdes. Satu diantaranya menginginkan tenaga kesehatan tidak hanya mengontrol ibu, tapi juga aktif dalam mengunjungi dan melihat tumbuh-kembang dan kesehatan anak, dan 2 diantaranya pun berharap obat-obatan dan vitamin dilengkapkan, lebih memperhatikan lagi ibu-ibu hamil dan melahirkan, serta memberikan informasi-informasi mengenai kesehatan lainnya. Seperti pernyataan berikut ini :

"harapan saya itu ya supaya tenaga kesehatan itu aktif di puskesdes. Jarang datang bu bidannya, ada lagi $t a$ ' 3, 4 hari, pulang lagi lama..(P1)

"saya mau dari bidan jangan pergipergi jauh, jangan pergi-pergi terus toh, ada terus di pustu, tetap disini." (P2)

"kalau untuk anak ku kan kalau sudah lahir mi ya harapan ku supaya datang terus menjenguk iii, datang terus naliat iii bagaimana perkembangannya, kesehatannya, itu ji." (P3)

“...kalau mau ku saya toh lengkap begitu, kan sekarang toh masih ada yang kurang begitu, macam obat-obatan tidak lengkap. Ya mudah-mudahan bisa $m i$ juga 
Jurnal Kesehatan Masyarakat, Vol. xx, No. x, 20xx: xx - xxp-ISSN: 2442-8884 / e-ISSN: 2541-4542

http://dx.doi.org/10.35329/jkesmas.vxxixx

lengkap begitu toh jadi nda jauh-jauh maki lagi kasian ke Polewali.”(P4)

"Harapan ku ya itu tadi oo eee ada itu kaya vitamin untuk anak, lebih di perhatikan lagi ibu-ibu hamilnya dan ibu melahirkannya." (P5)

Harapan yang di ungkapkan oleh partisipan diatas, sejalan dengan penelitian yang di ungkapkan oleh Andi syarkawi dan Muh. Anwar (2017), hasil penelitiannya menunjukkan bahwa ibu hamil dengan pengetahuan kurang dan tidak baik $(59,2 \%)$ yang artinya semakin besar pula kurangnya pengetahuan ibu hamil tentang pelayanan kebidanan maka akan semakin besar pula kurangnya jumlah kunjungan ke pelayanan kesehatan. Pengetahuan yang dimaksudkan dalam penelitian ini yaitu penyuluhan dan nasehat kepada program keluarga dan masyarakat terutama kepada ibu hamil tentang segala hal yang berkaitan dengan dengan kehamilan termasuk penyuluhan kesehatan umum, gizi, keluarga berencana, kesiapan dalam menghadapi kehamilan, dan menjadi calon orang tua, menghindari kebiasaan yang tidak baik dan mendukung kebiasaan yang baik.

Penelitian serupa juga di ungkapkan oleh Nurul Iatiqna (2015) bahwa secara keseluruhan, pelayanan belum memuaskan dimana terdapat nilai gap sebesar 0,07 dari segi variabel, pasien merasa belum puas terhadap kompetisi teknis petugas, akses pelayanan, efektivitas pelayanan, efesiensi pelayanan, kesinambungan pelayanan, keamanan, kenyamanan, informasi, ketepatan waktu, dan variabel hubungan antar manusia, dengan harapan agar pelayanan dapat meningkatkan pelayanan ketersedian obat, dan meningkatkan pelayanan pada item waktu tunggu pemeriksaan.

\section{KESIMPULAN}

Hasil penelitian menunjukkan bahwa pengalaman pereumpuan dengan persalinan pervaginam di usia dini di Desa Mambu Tapua dan Ba'ba Tapua di Wilayah kerja Puskesmas Matangnga yaitu pengalaman perempuan menjelang persalinan, persepsi adanya perubahan pola hidup pasca melahirkan, dampak pernikahan di usia dini, peran tenaga kesehatan terhadap pelayanan kesehatan, harapan terhadap pelayanan kesehatan.

\section{Ucapan Terima Kasih}

Kepala Puskesmas Kecamatan Matangnga beserta seluruh staf yang telah memberikan izin penelitian dan membantu dalam memperoleh data awal. Dan Seluruh partisipan yang telah meluangkan waktu dan berbagi pengalamannya selama dan pasca persalinan untuk penelitian ini serta Seluruh pihak yang telah membantu dalam menyelesaikan penelitian ini.

\section{DAFTAR PUSTAKA}

1. Afianti, Y \& Rachmawati, I.N. (2014). Metodologi penelitian kualitatif dalam riset keperawatan. Rajawali Pers: Jakarta. 
2. Amperaningsih, Y \& Siwi, P.N. (2018). Stres pasca trauma pada ibu post partum dengan section caesarea emergency dan partus spontan. Jurnal Keperawatan. 14 (1), diakses pada maret 2019, https://ejurnal.poltekkes-

tjk.ac.id/index.php/JpengaruhKEP/article/ view/1011.

3. BKKBN (2017). Usia Pernikahan Ideal 21-25 Tahun. Diperoleh dari https://www.bkkbn.go.id

4. Bobak, Lowdermilk, \& Jensen. (2012). Buku ajar keperawatan maternitas. EGC: Jakarta.

5. Creswell, John W. (2015). Penelitian kualitatif \& desain riset memilih diantara lima pendekatan. Pustaka Pelajar. Yogyakarta.

6. Damayanti, Ika Putri, dkk. (2014). Buku ajar asuhan kebidanan komprehensif pada ibu bersalin dan bayi baru lahir. Deepublish (Grup Penerbit CV Budi Utama): Yogyakarta.

7. BPS (2017). Perkawinan Usia Anak di Indonesia 2013 dan 2015. Jakarta: Badan Pusat Statistik.

8. BPS (2018). Provinsi Sulawesi Barat Dalam Angka 2018. Sulbar: Badan Pusat Statistik Provinsi Sulawesi Barat.

9. Dinas Kesehatan Provinsi Sulawesi Barat (2017). Profil Kesehatan Provinsi Sulawesi Barat 2017. Diperoleh dari https://www.depkes.go.id

10. Emilia, P.S, Candra, H.P. (2018). Hubungan tingkat kemampuan dalam merawat diri dan bayinya terhadap tingkat kecemasan ibu primigravida trimester ke tiga. Jurnal ilmu keperawatan jiwa 1 (12). ISSN 2621-2978. Diakses pada agustus 2019.

http://journal.ppnijateng.org/index.php/jikj /article/view/153/0

11. Fajarsari, D \& Prabandari, F. (2018). Pengaruh umur dan interval persalinan terhadap kejadian preeklamsia di Kabupaten Banyumas. Jurnal Publikasi Kebidanan. 9 (2), diakses pada maret 2019
https://ojs.akbidylpp.ac.id/indekx.php/Pra da/article/view/462.

12. Halimatussa'diyah. (2015). Tafsir kebencian studi bias gender dalam tafsir Al-Qur'an karya Zaitunah Subhan. Jurnal ilmu agama. 16 (1). Diakses pada juni 2019.

http://jurnal.radenfatah.ac.id/index.php/JI A/article/view/504/454

13. Jekti, R.P \& Suarthana, E. (2011). Risk factors of post partum haemorrhage in indonesia. 2 (2), diakses pada juni 2019. https://www.neliti.com/id/publications/56 141/risk-factors-of-post-partumhaemorrhage-in-indonesia.

14. Kementrian Kesehatan Republik Indonesia (2018). Hasil Utama Riskesdas 2018. Jakarta: Kementrian Kesehatan RI.

15. Kurniasari, D \& Astuti, Y.A. (2015). Hubungan antara karakteristik ibu, kondisi bayi dan dukungan suami dengan postpartum blues pada ibu dengan persalinan SC di rumah sakit umum Ahmad Yani Metro tahun 2014. Jurnal Kesehatan Holistic. 9 (3), diakses pada juni 2019. http://malahayati.ac.id/?p=31458.

16. Mansur, H (2014). Psikologi ibu dan anak untuk kebidanan. Salemba Medika: Jakarta.

17. Manuaba, 2012. Ilmu Kebidanan, Penyakit Kandungan, dan Keluarga Berencana untuk Pendidikan Bidan. EGC: Jakarta.

18. Mery, M, Dien, G.A.N, Livia, R. (2015). Peran tenaga kesehatan dan keluarga dalam kehamilan usia remaja. Jurnal kesehatan masyarakat nasional 10 (2), diakses pada juni 2019. http://journal.fkm.ui.ac.id/index.php/kesm as/articel/view/885

19. Nelly Karlinah, Serudji, J, Syarif, I. (2015). Pengaruh tehnik akupresur dan TENS terhadap intensitas nyeri persalinan kala I fase aktif. Jurnal Kesehatan 4 (3), diakses pada agustus 2019. http://jurnal.fk.unand.ac.id 
20. Nevid, Rathus \& Greene. (2010). Psikologi abnormal, Jilid I. Alih Bahasa, Tim Psikologi UI. Erlangga: Jakarta.

21. Oktarina, Mika. (2016). Buku ajar asuhan kebidanan persalinan dan bayi baru lahir. Deepublish (Grup Penerbit CV Budi Utama): Yogyakarta.

22. Palupi, D.D \& Indrawati, R. (2014). Faktor resiko kematian ibu dengan preeklamsia/eklamsia dan perdarahan di Provinsi Jawa Timur. Jurnal Biometrika dan Kependudukan. 3 (2), diakses pada tanggal maret 2019, http://repository.unair.ac.id/23823/.

23. Pujiati, W, Nirnasari, M, Hotmaria, J.D.S, Daratullaila. (2019). Aromaterapi kenanga dibanding lavender terhadap nyeri post section carsaria. Jurnal Keperawatan Silampari, 3 (1), e-ISSN 2581-1975, pISSN 2597-7482. Diakses pada agustus 2019. https://doi.org/10.31539/jks.v3i1.534

24. Qiftiyah, M. (2018). Gambaran faktorfaktor dukungan keluarga, pengetahuan, status kehamilan dan jenis persalinan yang melatarbelakangi kejadian postpartum blue pada ibu nifas hari ke 7 (di polindes doa ibu gesikharjo dan polindes teratai kradenan palang). Jurnal Kebidanan. 10 (2), diakses 12 juni 2019, https://www.researchgate.net/publication/ 330286652_Gambaran_FaktorFaktor_Duk ungan_Keluarga_Kehamilan_Dan_Jenis_ Persalinan

25. Rohmi, H, Dyah, F, Dwi, R.T.A, Dewi, N.R. (2016). Pengaruh terapi murottal AlQur'an untuk penurunan nyeri persalinan dan kecemasa pada ibu bersalin primigravida kala I fase aktif di RSUD Prof.Dr. Margono Soekardjo tahun 2014. Jurnal ilmiah kebidanan. 7 (1), diakses pada juni 2019. http://www.akbidylpp.ac.id/ojs/index.php/ Prada/article/viewFile/147/135

26. Saryono \& Anggraeni, D.M. (2013). Metode penelitian kualitatif dalam bidang kesehatan. Nuha Medika: Yogyakarta

27. Satriyandari, Y \& Hariyati, N.R. (2017). Faktor-faktor yang mempengaruhi kejadian perdarahan postpartum. Journal Of Health Studies. 1 (1), diakses pada juni 2019. https://ejounal.unisayogya.ac.id/download $/ 185 / 121$.

28. Stuart, Gail W. (2013). Buku saku keperawatan jiwa. EGC: Jakarta.

29. Sugiarto. (2017). Sulbar juara satu kasus pernikahan dini se-Indonsi, Tribun news.com, diakses pada maret 2019., http://www.tribunnews.com/regional/2017 /10/18/sulbar-juara-satu-kasus pernikahandini-se-indonesia

30. Sugiyono. (2016). Metode penelitian kualitatif, kuantitatif dan R \& D. Alfabeta: Bandung.

31. Syamsuddin, AB. (2018). Pola dakwah perubahan sosisal. Jurnal tabligh 19 (2). Diakses pada agustus 2019). http://journal.uin-alauddin.ac.i

32. Syarkawi, A, Anwar, M. (2017). Gambaran pengetahuan sikap dan dukunan keluarga oleh ibu hamil terhadap pelayanan kebidanan di wilayah kerja puskesmas. Jurnal kesehatan masyarakat 3 (2), p-ISSN 2442-8884, e-ISSN 25414542. Diakses pada agustus 2019. https://journal.lppmunasman.ac.id/indx.php/jikm/article/view/ 249

33. The Global Goals For Sustainable Development (2019). Dieproleh dari www.globalgoals.org

34. World Health Organization (2018). Coming of Age: Adolescent Health. Diperoleh dari http://www.who.int 